Journal of Sustainability Perspectives

journal homepage: https://ejournal2.undip.ac.id/index.php/jsp/

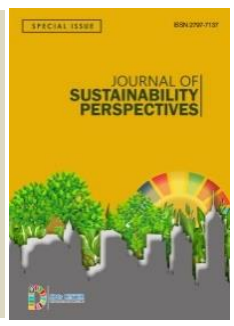

\title{
Building a Sustainable University Campus in Turkey: The Case of Istanbul Sabahattin Zaim University
}

\author{
Mehmet Bulut ${ }^{1, *}$ \\ ${ }^{1}$ Istanbul Sabahattin Zaim University, Halkalı Mahallesi, Halkalı Kampüsü Halkalı Caddesi, 34303 \\ Küçükçekmece/Istanbul Turkey \\ *corresponding author: mehmet.bulut@izu.edu.tr
}

\section{Article Info}

\section{Received:}

15 March 2021

Accepted:

25 May 2021

Published:

1 August 2021

DOI:

Presented in The $6^{\text {th }}$ International (Virtual) Workshop on UI GreenMetric World University Rankings (IWGM 2020)
Abstract As defined by Brundtland (1987), sustainable development is that which seeks to meet the needs of the present generation without compromising the ability of future generations to meet their own needs. This requires however, a holistic approach to defining appropriate philosophies and more ethical yet creative solutions vis-a-vis climate change, poverty elimination, countering inequality, preserving earth and striving for prosperity. Educational institutions, and especially those of higher learning, have a major role to play in this domain. This paper sheds light on the share of responsibility taken at Istanbul Sabahattin Zaim University (IZU) towards sustainable development goals and world's complex challenges, and most importantly, its best practices in the management of $\mathrm{UI}$ GreenMetric indicators. This study explores some of IZU's current approaches and strategies adopted in the context of Turkish Waqf based higher learning institutions, and particularly, the ways and means according to which IZU continues to manage core domains of sustainable development and green initiatives whether related to setting and infrastructure, energy and climate change, waste, water, transportation or education, in addition to its various contributions to make to education and training, research and application, disseminating of ethics of green, and strengthening of its broad yet inclusive community engagement and global partnership support and development. This research shows that IZU's investment in sustainability interestingly represents one of its foundational core ethical values disseminated, and that its broad-spectrum practices, strategies, policies and systems of operation and management are underpinned in its very cultural and historical fabric of planetary preservation and stewardship.

\section{Keyword:}

Istanbul Sabahattin Zaim University. Sustainable Development. University

Social Responsibility. Green Campus. UI Green Metric 


\section{Introduction}

As an educational institution, the history of Istanbul Sabahattin Zaim University (IZU) reaches to the end of the 19th century. Formerly it was established as an Agriculture and Veterinary School and officially used since 1892 whose civil service veterinarians were the first graduates of Halkalı Agricultural School. Famous intellectuals such as Mehmet Âkif Ersoy (the Turkish National Anthem Poet) and other 19 students graduated in 1893. Mehmet Akif Ersoy was both an alumni and former staff member of its Veterinary School.

During WWI, the education stopped, however, because of the needs to agricultural production, the school reopened again in 1916. In 1922, and for the for the first time, the historical buildıng served as Rectorate. In 2010, the land which belonged formerly to Sultan II. Bayezid-I Veli Foundation and which hosted several key educational institutions during the Ottoman modernization process was finally transferred to the 'Knowledge Dissemination Foundation' for the sake of current IZU campus in 2010. After 10 years of its opening, today IZU campus serves around 10 thousand students. Istanbul Sabahattin Zaim is a non-for-profit waqf-based private higher educational institution located in the picturesque historical Waqf site on the European part of Istanbul. The concept of endpwmnet (waqf) takes its origin from "sadaqatul jariyah" - a sustainable charity philosophy highly encouraged in the Islamic religion.

IZU campus is located is located in the western side of Istanbul in the Halkali/ Kucukçemece district. The latter has a surface area of approximately 37,75 square kilometers and a perimeter length of 47,33 kilometers. The total population of the district is 792.821 with a population density of 21.001per square kilometers. The total area of IZU main campus is $629.512,48 \mathrm{~m}^{2}, 279,987 \mathrm{~m}^{2}$ of which is for the current university use and the remaining is woodland and empty land. The total main campus green area is $48,760 \mathrm{~m}^{2}$, while $60.880 \mathrm{~m}^{2}$ is covered in Forest Vegetation. Initiatives of plantation for workers (parts of empty campus land).

As a young and fast growing university, IZU strives to be a leading international research university recognized for its academic excellence, pioneering publications, distinguished graduates and advanced infrastructure, while ranked among the top fivenonprofit Waqf universities in Turkey. The university has strong academic and research base on in the social sciences and humanities as well as engineering and architecture. ISU is committed to shaping virtuous leaders of the highest calibre and skills, who are dedicated to pursuing scientific inquiry and serving humanity. environmental stewardship is one of IZU's core values besides scientific inquiry, integrity, fairness, academic freedom, justice, originality, innovation, respect, assertiveness and environmental stewardship.

\section{On Campus Green and Sustainability}

In the last 70 years, the world population has tripled while cities grew to the dimensions of metropolises and megapolises. Nowadays already $55 \%$ of the world's population live in cities. In 2050, only $30 \%$ of human beings will live in rural settlements. Because of the high density of cities architecture, urban design and city planning gain significant importance. Architecture in relation to transportation and infrastructure as human impact on nature has reached a historical dimension and caused climate change. The natural environment is adversely affected by rapid urbanisation such as loss of green areas and natural sources as well as pollution. In the 1970's, the green movement started in architecture, with the first attempt just "fashion", however nowadays the importance of sustainability within architecture is beyond dispute. The sustainability strategies in 
architecture range from heating insulation of a facade, green facades and roofs, eco-bridges to eco-master planning.

Universities play a fundamental role in the education, practise and improvment of sustainability. Istanbul as the cultural capital of Turkey has the highest number of universities in the country. The number of students rises continuously. According to the increase in students' number, IZU has developed a sustainable growth strategy for its campus. The first step was to efficiently reuse its historical buildings. Thus several renovations have been done carefully. The old barn, the greenhouse and the gardeners' house were converted to social activity areas and used today as cafes. An ancient village with a basilica situated in the campus is currently being excavated and will welcome its visitors soon. By renovations of historical buildings and excavation of ancient heritage, cultural sustainability is also achieved. All unused space (depot, garage etc.) have undergone a redesigning process and created new useful areas for student's gathering and needs. The historical main building itself is used for various functions. Beside the Rectorate' administrative offices, space for education like classrooms, research labs and exhibitions like museums are also provided.

According to IZU philosophy, it is believed that every piece of land should be used, for unused represents waste. Some part of the empty land is used for staff hobby gardens for plantation and vegetables harvest. The campus is astoundingly evergreen with a marvelous view on the Kucukcekmece Lake. After having reused all possible architectural heritage, new sustainable buildings have been added to the campus according to new sustainability standards. All new buildings in IZU campus are designed with large joinery in order to get maximum daylight advantage. The buildings are designed with courtyards which bring the light and fresh air to the inner spaces. Domestic material has been used in the building of facade. Integrated facade sun protection elements help decrease cooling energy.

And with the goal of cultural sustainability, new buildings are designed with an interpretation of traditional Ottoman architecture (archs, domes, courtyard, sun protection elements, window dimensions etc.). All of IZU campus buildings are designed carefully in harmony with nature and are built in such a way that does not affect the environment aesthetically. The historical building, which includes the rectorate office, is square shaped when viewed from above, and it has two floors. It has stone walls which are about $80 \mathrm{~cm}$ thick. In the inner and outer garden, some trees are about 100 years old. A support equipment was placed on the trunk of an old tree that dries in front of the main entrance of the historical building. Now its name is "memorial tree". The buildings afterwards of the campus have three floors at most. The exterior of all buildings is designed to combine the university's historical and innovative mission.

The culture of animal friendly in university has shown clearly in the number of animals living peacefully on its campus with the understanding and caring manner of the academic staff and students. The flora spectrum of the campus is also diverse and spans from conifers to palmas, snow white chamomiles to rainbow tulips. The campus is also a lovely habitat for students and for fauna as well. The squirrels, hedgehogs and African parrots are just a tip of the astonishing fauna iceberg of the IZU campus. Cats are fed on by anyone on campus. The university provided many trees with hanging birdhouses. IZU campus has the flora spectrum with diverse types of trees and flowers. IZU planted many types of flowers almost at each building. It spans from conifers to palmas, from snow white chamomiles to rainbow tulips. The university provided benches or garden areas for students and academic staff to conduct their discussions or picnics surrounded by colourful flowers and different types of 
trees. At IZU campus, every on-campus tree has a number tag and is documented in the Waqf inventory registrar. Numbered trees are not allowed to be cut due to the location of the buildings, as well as roads must be carefully drafted in order to complement the harmony of the green nature and required to comply with the Waqf registration law.

\section{Energy, Emission and waste management}

The major problems facing the world today are energy shortage and environmental pollution. IZU has made contributions in the field of renewable energy technology, energy saving and environmental protection in which supporting sustainable development by zero emission policy. In addition, it is a training base for students on environmantal and sustainablity practices and serves as a model for leading academic staff and students to achieve green, low carbon and sustainable development. IZU continuously increases its energy saving systems appliances and activities through use of insulation, LED lighting and the deployment of sustainable technology. In addition, all printers in the campus are set to go into sleep mode within 60 minutes as well as all computers in 15 minutes. This automation provides energy saving. Moreover, $87 \%$ of led lamps on the campus (7400 out of 8500) are energy-efficient appliances.

IZU campus buildings are also designed with large joinery in order to get maximum daylight. Buildings are designed as inner courtyards and the light facing of the inner and outer spaces is provided. The roof skylights transmitting maximum daylight into the building, as in the new mosque and library, leading to minimized consumption of electricity and heating energy, and thus energy saving. Modern methods have adopted with regards to facade insulation aiming at heat loss reduction. Corridors are also designed to be wide and open to the atmosphere and the utilization of natural ventilation is kept at the highest level. Natural materials such as wood was used in the interior design and infrastructure of both the mosque and the library. The use of the equipment such as air conditioners and refrigerators have been minimized. In addition, because most of the roof of the library is made of smart glass, it provides a significant efficiency from daylight and minimizes the use of air conditioners. IZU campus mosque and main library were built at the same time, both of them have two floors which fit the capacity of students and both are near one another. During exams, the library stays open 24 hours, however, lights at level 2 are turned off at 12 midnight. In this way, students learn the importance of saving.

A low carbon future means a more vibrant economy instrmental to adaptation of climate science and clean technology. IZU aims to improve the transportation infrastructures in accordance with the principles of sustainability and is working to decarbonize its campus transportation fleet by implementing an effective policy. The first policy is a shuttle service with its own route and schedule. This is set to reduce emissions, reduce traffic, not to speak about saving staff and students time and energy. One of initiatives is to decrease private vehicles on campus, and hence private vehicles are not allowed on campus except for special circumstances. Academic staff are allowed to park at the back gate parking area or main gate with limited parking space near the guard house. The university provided electric vehicles for daily activities on campus with parking guidance systems and students with free bicycles on campus. Since students are not allowed to enter the university with their cars, instead of riding a bicycle, many have chosen to walk on campus at pedestrian pathways. It is safer, healthier, and more cost effective. It is characterized by a path of greenways that goes beyond recreation and beautification to address such beautiful flora, fauna and enhance biodiversity around campus. 
There are currently 28 solar panels in the size of $1988 \times 1218 \mathrm{~mm}$ installed up on the roofs of sport buildings. This ensures provision of hot water needs in the area. IZU campus total electricity usage (Electricity Usage per Year (in Kilowatt hour) in 2018 is reported to be 3.360.556,52 kWh.IZU main campus area, used electricity for lighting, cooling, heating and laboratory appliances. The total natural gas consumption of IZU Campus in 2018 is 759.925 $\mathrm{m}^{3}$. However, in the last two years, there has been an increase both in the number of students and in the indoor closed area. Although electricity and gas use rates appear to have slightly increased, the average energy use per student and indoor closed area has decreased by 20 percent.

\begin{tabular}{lll}
\hline & $\mathbf{2 0 1 7}$ & $\mathbf{2 0 1 8}$ \\
\hline Number of Students & 8.865 & 10.551 \\
Indoor Closed Area $\left(\mathrm{m}^{2}\right)$ & 68.032 & 92.212 \\
Electricity usage & $2.904 .506,04 \mathrm{kWh}$ & $3.360 .556,52 \mathrm{kWh}$ \\
Naturalbgas & $616.989 \mathrm{~m}^{3}$ & $759.925 \mathrm{~m} 3$ \\
consumption & & \\
\hline
\end{tabular}

As far as waste management is concerned, IZU Campus has a centralized timertriggered electricity and water management system. The university also supports a recycling program to manage waste by providing a recycle bin at each department. An online program is implemented to address classroom waste already in place before COVID pandemic. The solution of using the Team's platform was appropriate and protects the wellbeing of students and faculty members while maintaining efficiency and reducing energy. IZU also helps students reduce use of paper through sharing learning materials on the website or e-classroom files and ebooks. Students are required to email instead printing and submit their assignment paper. With regards to food and wastage, the food is placed in a medium portion to avoid wasting. Paking food is not allowed. Wastage of food should is placed by users themselves in the designated dishwasher area. The university also supports a recycling program and provides recycle bins at each department or offices.

\section{Education and Research}

IZU offers varierty of courses related to sustainability and environmental education. One of those is 'Information Social Responsibility and Ethics' which aims to educate students in the context of thinking, researching, reviewing, applying and producing knowledge in addition to develop students' social responsibility and ethical consciousness. In this course, students are also expected to do some voluntary work related to community and environment.

IZU academic staff and reseachers are provided with funding opportunities and grants and are highly encouraged to explore easpects of sustainability and publish in related areas. In addition, IZU also works closely on diverse issues of sustainability such as Islamic finance and Waqf using appraochs that are interdisciplinary and multidimensional. In addition, "Sustainable Development, Finance and Environment" working group in accordance with TÜBA Turkish Academy of Sciences is also addressing variety of sustainability related issues and problems Including zero waste and circular economy. With the philosophy of waste 
management based on the principles of zero waste and preventing wastage, recycling and efficient usage it is the aim of the working group to cooperate and discuss current environmental issues intensely with all institutions of the country in order to hand down a green future for the next generations.

In its way to conslidate its efforts to the achievement of SDG 4 concerning education, IZU provides opportunities to many international students, especially from war zones anc conflict areas, however with total or partial financial support, including students refugees, or students from Yeman and Africa. The university and llim Yayma foundation preferred to help students who had financial difficulties. However, the university also offers a discount to all students for a certain percentage either $50 \%$ or $70 \%$ of the total fee.

IZU Community Health \& Wellness

IZU set many strategies to further cultivate its culture of wellness among staff and students. Given teh busy streets and traffic of Istanbul, lecturers and students can fill their quality time by staying indoors surrounded with nature. They can also benefit from all the available sports facilities such the football stadiums, tennis courts, mini golf, volleyball and basketball. The IZU team is so far one of the best, with the canoe club as one of the attractive clubs by the Kucukcekmece lake. Food hygien and management ensure fresh, healthy, and diverse recipes selection.

The proximity of faculty buildings, dormitories, residence halls, outdoor sport facilities, library, mosque, dining hall, cafeterias, shorten the walking distance signifcantly. There are currently two students' residence complex buildings; one for males and the other for females, with a capacity of 300 students each. Residing in the dormitory saves the students not only the opportunity time of stacking in the traffic jams but also the opportunity time of cooking and washing dishes. Students who reside in-campus are offered free of charge breakfast and dinner and a lunch menu at a discounted fee. The dormitory facilities have free of charge indoor gym, cinema hall, prayer rooms, laundry, multipurpose saloon, cafeteria, study halls and of course $24 / 7$ free Wifi.

\section{Summary/ Concluding Remarks}

IZU leans on an old Ottoman tradition of learning, environment stweardship, cultural sustainability, and service to the community and the world. Along those paths, IZU pursues its ambitions of green and sustainability, through adherence to modern environmental standards of architecture, energy, nature, and more importantly perhaps the education and research that echo the true sense of caring about nature and environment in general. At the core of building green and sustainability, IZU's core focus is on the learners' education and development according to universal values that would not produce responsible citizens for Turkey but the whole world. IZU will its dooes of learning always open and shall continues to learn about any other good practices in the field and incorporate them in its impleentation plan.

\section{References}

1. Attia, Shady (2018): Regenerative and Positive Impact Architecture. Learning from Case Studies. Springer. [online] Available from: https://orbi.uliege.be/bitstream/2268/213357/1/Fina\%2010.1007\%252F978-3-31966718-8.pdf [accessed 3 May 2020].

2. Ilim Yayma foundation (2020): https://www.iyv.org.tr/tr/ist-sabahattin-zaimuniversitesi.html [accessed 3 May 2020]. 
3. Interview with Prof. Arif Ersoy, Department of Islamic Economy and Finance, Istanbul Sabahattin Zaim University, 23.04.2020.

4. IZU (2020): https://www.izu.edu.tr/en/about-izu/history/about-izu [accessed 3 May 2020].

5. IZU Institutional Assessment Report 2016 [online]. Available from: https://www.izu.edu.tr/docs/default-source/kalite-politikas\%c4\%b1-

raporlar\%c4\%b1/20160715_kurumicdegerle.pdf?sfvrsn=c9abc235_4 [accessed 3 May 2020].

6. IZU Sustainability Report 2018 [online]. Available from: https://www.izu.edu.tr/docs/default-

source/s\%C3\%BCrd\%C3\%BCr\%C3\%BClebilirlik/iz\%C3\%BC-

s\%C3\%BCrd\%C3\%BCr\%C3\%BClebilirlik-raporu-2018.pdf [accessed 3 May 2020].

7. Statista (2020): https://www.statista.com/statistics/264651/proportion-of-populationin-cities-worldwide/ [accessed 3 May 2020].

8. Şimşek, Onur (2016): Friedensreich Hundertwasser, A Visionary Ecological Design. DCA 2016 Design Communication European Conference, pp. 448-456

9. IZU 2017-2021 Strategy Plan [online]. Available from: https://www.izu.edu.tr/izuhakkinda/strateji-ve-yonetim-sistemleri/stratejik-plan [accessed 3 May 2020].

10. Küçükçekmece Belediyesi Konumu [online]. Available from: https://kucukcekmece.istanbul/icerikler/kucukcekmece/konumu/708 [accessed 3 May 2020]. 